\title{
Sterke omzetgroei ambulant pedicures
}

\section{Pedicures kijken met gemengde gevoelens terug op het jaar 2017. Een pedicure met een eigen praktijk aan huis boekte in het jaar 2017 18,4 procent minder omzet dan in het voor- gaande jaar. Pedicures die in een bedrijfspand zijn gevestigd noteerden een omzetdaling van 17,4 procent. Ambulante pedicures daarentegen boekten 19,2 procent meer omzet.}

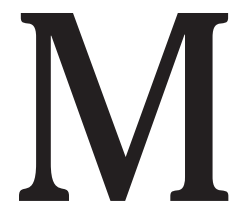
arktdata.nl meet periodiek met het pedicure- en schoonheidsspecialistenpanel de omzetontwikkeling van pedicures in Nederland. In de analyses wordt onderscheid gemaakt tussen pedicures die voornamelijk vanuit het eigen huis werken (bijvoorbeeld een ruimte in het eigen huis, aanbouw of verbouwde garage gebruiken voor het uitvoeren van behandelingen en schoonheidsspecialisten), die vanuit een bedrijfspand opereren (bijvoorbeeld een professionele pedicuresalon met personeel in een stadscentrum) en ambulante pedicures die hoofdzakelijk bij de klant thuis voetverzorging uitvoeren.

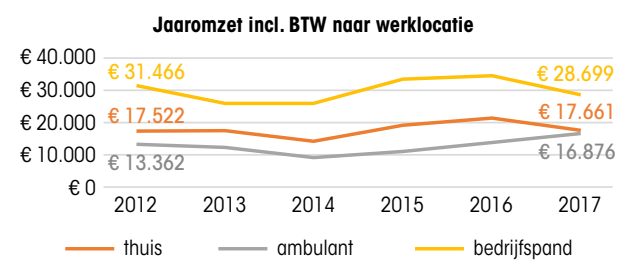

Pedicures die vanuit een bedrijfspand werken realiseren een beduidend hogere omzet dan de vanuit het eigen huis of ambulant werkende pedicures. In het jaar 2017 boekte een vanuit het eigen huis werkende pedicure een gemiddelde omzet van krap 18.000 euro (incl. btw). Ambulante pedicures boekten krap 1000 euro minder omzet dan de vanuit het eigen huis werkende ondernemers.

Een jaar eerder behaalden de vanuit het eigen huis werkende pedicures nog grofweg de helft meer omzet dan een ambulante voetverzorger.

Pedicures die vanuit een bedrijfspand werken behaalden in het jaar 2017 een omzet van bijna 29.000 euro (incl. btw). Onderstaand figuur toont het indexcijfer van de jaaromzet, waarbij het jaar 2012 op 100 is gesteld.

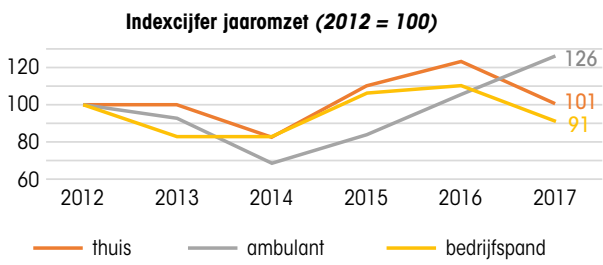

In het jaar 2014 lag de jaaromzet van zowel pedicures die vanuit het eigen huis werken als ambulante pedicures en die vanuit een bedrijfspand werken onder het niveau van het jaar 2012.

De afgelopen 3 jaar zien we een flinke omzetgroei bij de ambulante voetverzorging. De vanuit een bedrijfspand werkende pedicures boekten in het jaar 2017 gemiddeld 9 procent minder omzet dan in het jaar 2012. De vanuit het eigen huis werkende pedicures noteren een bescheiden omzetgroei van 1 procent over de afgelopen 5 jaar. Ambulante pedicures daarentegen noteren een omzetgroei van 26 procent ten opzichte van het jaar 2012. Ambulante pedicures lijken daarmee goed in te spelen op de toenemende vergrijzing en het gemeengoed worden van het uit de luie stoel bestellen van diensten en producten met thuisbezorging.

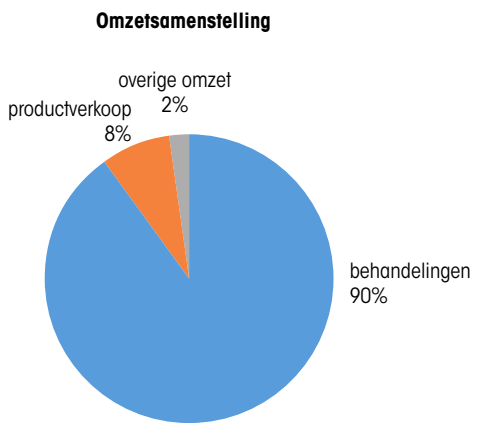

De belangrijkste inkomstenbron van een pedicurepraktijk is het uitvoeren van behandelingen bij klanten. Voetverzorging als behandeling vertegenwoordigt gemiddeld 90 procent van de omzet. Gemiddeld realiseert een pedicurepraktijk 8 procent van de omzet met de verkoop van producten. Onderstaand figuur toont de ontwikkeling van de omzetaandelen naar type pedicure.

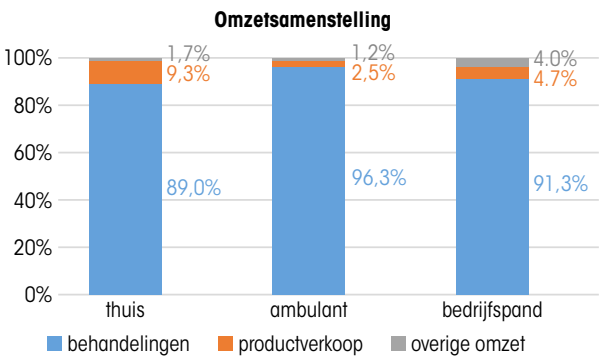

De vanuit het eigen huis werkende voetverzorgers behalen nog het grootste omzetaandeel met de verkoop van producten $(9,3 \%)$ procent. Ambulante pedicures behalen vrijwel alle omzet met het uitvoeren van behandelingen. 